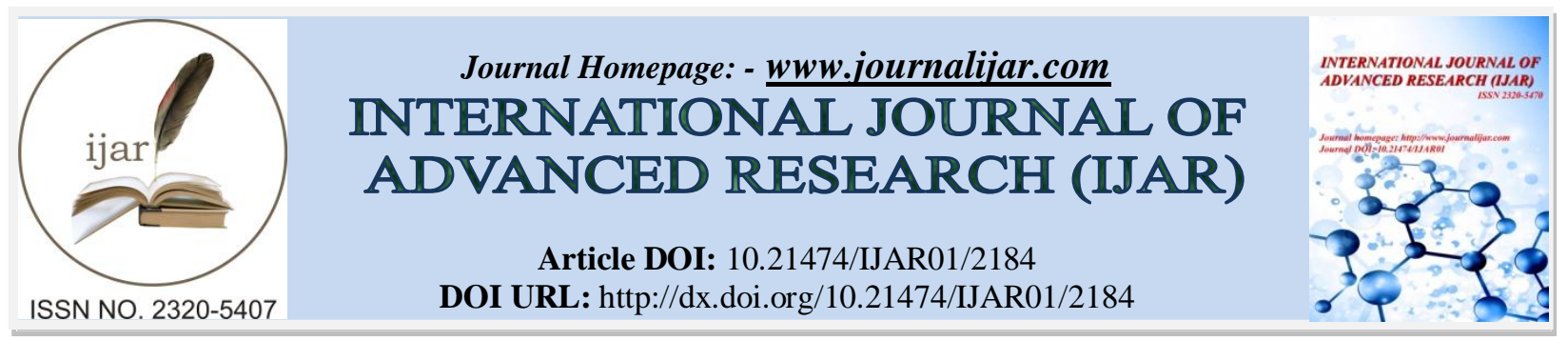

RESEARCH ARTICLE

\title{
HYDROCHEMISTRY OF WATER SPRINGS OF THE TRAVERTINE AQUIFER OF GUELMA IN NORTH-EAST OF ALGERIA.
}

*Nouar T., Geroui Y. and Toumi A.

Civil Engineering and Hydraulic Laboratory, PO Box 401, University 8 mai 1945, Guelma, 24000. Algeria.

\section{Manuscript Info}

Manuscript History

Received: 27 September 2016

Final Accepted: 30 October 2016

Published: November 2016

Key words:-

Hydrochemistry, travertine aquifer, quality, Guelma, Algeria.

\section{Abstract}

This work was conducted on ten water springs of the travertine aquifer of Guelma in north-east of Algeria. The physical parameters $(\mathrm{pH})$, Electric Conductivity (EC), Total Dissolved Solids (TDS), TH as well as the concentrations in major ions $\mathrm{Ca}^{2+}, \mathrm{Mg}^{2+}, \mathrm{Na}^{+}, \mathrm{K}^{+}, \mathrm{Cl}^{-}, \mathrm{SO}_{4}{ }^{2-}$, $\mathrm{HCO}_{3}^{-}, \mathrm{NO}_{3}^{-}$and $\mathrm{SiO}_{2}$ analyzed by standard methods. Hydrochemical facies predominant in the study area is $\mathrm{Ca}-\mathrm{Mg}-\mathrm{HCO}$. Water-rock interaction characterized by the dissolution of carbonates and silicates plays a primordial role in the chemical composition of the groundwater. The hydrochemical study of the area showed that the majority of cations and anions, electric conductivity, the TDS and the $\mathrm{TH}$ which characterize the chemical composition of the aquifer are within the limits allowed for the drinking water according to WHO guidelines purposes. Soluble sodium percent, SAR, RSC and Magnesium hazard reveal that, barring a few locations, most of the groundwater samples are safe for irrigation purposes.

Copy Right, IJAR, 2016,. All rights reserved.

\section{Introduction:-}

In Algeria and in Guelma in particular, the supply of water for different purposes depended largely on groundwater, where the surface waters are heavily polluted. Economic development, agriculture and population growth result in an increased need exceeding the potentialities of the alluvial aquifer, which requires capturing springs witch emerge from the travertine aquifer. Ultimately, to satisfy the suburban area in water for human consumption and water demand for crops irrigation. The main objectives of this study are physicochemical parameters, the identification of chemical processes that are responsible of groundwater chemistry and suitability for drinking water and irrigation purposes of the waters springs of the travertine aquifer.

\section{Material and Methods:-}

Seven major waters springs (Table 1) were sampled in May 2016 for the purpose of this investigation. The geographical location of the sampling sites is shown in Figure1. Field measurements of TDS, pH and alkalinity were determined at all sampling sites. Alkalinity was determined using colorimetric titration with sulphuric acid $(0.1 \mathrm{~N})$. Other chemical analyses $\left(\mathrm{Ca} 2+, \mathrm{Mg} 2+, \mathrm{Na}+, \mathrm{K}+, \mathrm{CI}-, \mathrm{SO}_{4}^{2-}, \mathrm{NO} 3-\right.$ and dissolved silica) and isotopic analyses were carried out later in the laboratory. Calcium, $\mathrm{Mg} 2+, \mathrm{Na}+\mathrm{K}+$ and aqueous silica concentrations were determined by flame photospectrometry. Concentrations of Chloride, Nitrates and sulfates were determined using ion chromatography at the Civil Engineering and Hydraulic Laboratory at Guelma University. The hydrochemical calculations were performed using the Diagram program (Simler, 2003), which makes it possible using PHREEQC

Corresponding Author:- Nouar T.

Address: Civil Engineering and Hydraulic Laboratory, PO Box 401, University 8 mai 1945, Guelma, 
(Parkhurst and Appelo, 1999). The computer processing of these hydrochemical data had a main objective: the determination of the saturation indexes of minerals such, Aragonite, calcite, dolomite, chalcedony, quartz, amorphous silica and gypsum, and the partial equilibrium pressure of $\mathrm{CO}_{2}$.

\section{Study Area:-}

The study area is located in Guelma district in the extreme North East of Algeria with a surface of about $13 \mathrm{~km}^{2}$. The travertine aquifer constitutes an important water resource not exploited by boreholes. Many springs emerge in this locality and its water contributes in drinking purposes and irrigation of the south part of Guelma. The study area is characterized by an elevation of about 250 to $575 \mathrm{~m}$ above the sea (msl). The outcrops are occupied by the mastic and olives trees in South, and cereals; fruit trees and vegetables in North. In the center, they are occupied by urban zone extension of Guelma City(Figure1).The climate of the study area is considered to be semi tempered, the annual average precipitation being approximately $555 \mathrm{~mm}$. Rainfall occurs from august to June, with a maximum during January and February of each year. The average temperature is approximatively $12^{\circ} \mathrm{C}$ in winter and $26^{\circ} \mathrm{C}$ in summer, though summer high temperature can reach $40^{\circ} \mathrm{C}$ in July. Annual total evaporation rises to $886.71 \mathrm{~mm}$. The geology of the area was studied by several authors (Vila, 1980; Chouabbi 1987).It consists by travertine rich with aragonite, calcite and siliceous jasper bedded on Pliocene clay basement. The aquifer is mainly recharged by precipitation, secondarily by the contacts with the Numidian sandstones in South of the study area (Benmarce, 2007).

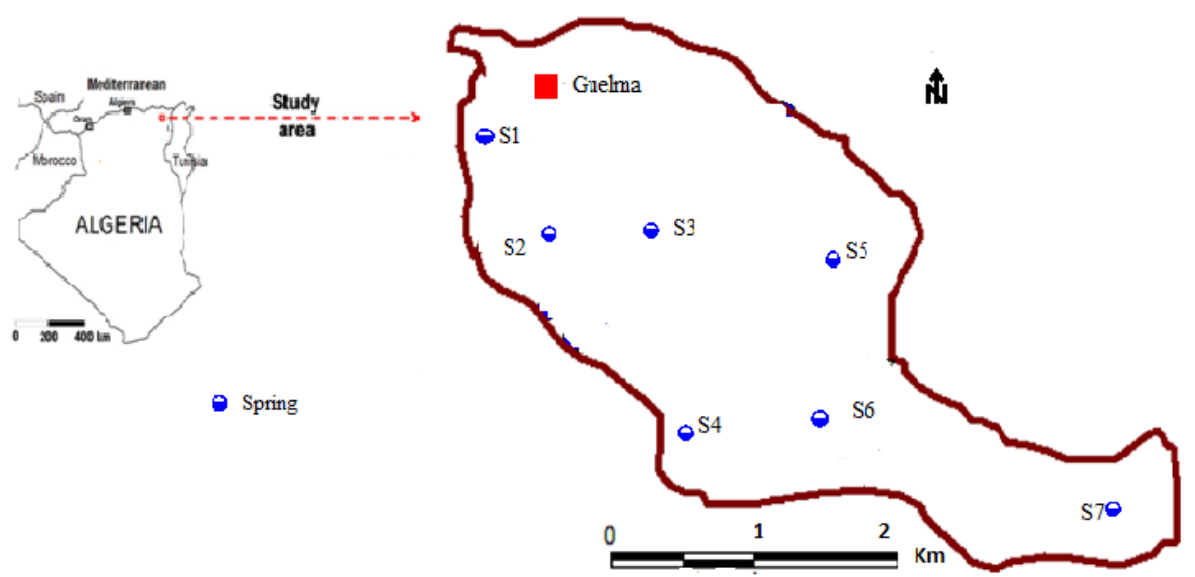

Fig 1:- Location of the study area in eastern part of Algeria

\section{Results and Discussion:}

\section{Chemical Characteristics:}

Physical and Chemical data, minimum, maximum, mean and Standard deviation of all the springs water are summarized in Tables 1and 2.Among the major cations (Table 1), a predominance of $\mathrm{Ca}^{2+}$ and $\mathrm{Na}^{+}$is observed for this groundwater samples. Concentrations of both $\mathrm{Ca}^{2+}$ and $\mathrm{Na}^{+}$(in $\mathrm{mg} \mathrm{1-1)}$ ) represent on average 67.27 and $26.15 \%$ of all the cations, respectively. $\mathrm{Mg}^{2+}$ and $\mathrm{K}^{+}$ions are secondary in importance, representing on average $11.58 \%$ of all cations. Among the major anions (table 1), $\mathrm{HCO}_{3}^{-}$is also dominated, representing on average $73.69 \%$ of all the anions. The $\mathrm{Cl}^{-}, \mathrm{SO}^{2-}{ }_{4}$ and $\mathrm{NO}_{3}^{-}$ions are less abundant; they represent on average 15.80, 8.29 and $2.19 \%$ of all the anions, respectively. The concentrations of dissolved silica are heterogeneous, varying between 5.70 and $13 \mathrm{mg} / 1$.

Table 1:- Chemical composition (in $\mathrm{mg} / \mathrm{L}$ ) of groundwater from Travertine aquifer.

\begin{tabular}{|l|l|l|l|l|l|l|l|l|l|l|l|l|l|}
\hline ID & TDS & $\mathrm{pH}$ & $\mathrm{EC}$ & $\mathrm{TH}$ & $\mathrm{Ca}^{2+}$ & $\mathrm{Mg}^{2+}$ & $\mathrm{Na}^{+}$ & $\mathrm{K}^{+}$ & $\mathrm{HCO}_{3}^{-}$ & $\mathrm{Cl}^{-}$ & $\mathrm{SO}_{4}^{2-}$ & $\mathrm{NO}_{3}^{-}$ & $\mathrm{SiO}_{2}$ \\
\hline S1 & 550 & 7.53 & 683 & 316.50 & 110 & 10 & 42 & 1.72 & 269 & 63 & 22 & 4.30 & 8.20 \\
\hline S2 & 548 & 756 & 704 & 278.50 & 95 & 12 & 53 & 2.50 & 256 & 65 & 48 & 6.23 & 6.23 \\
\hline S3 & 592 & 7.50 & 752 & 322 & 102 & 16.16 & 52 & 2.22 & 298 & 78 & 24.6 & 5.70 & 5.70 \\
\hline S4 & 585 & 7.60 & 708 & 300.50 & 87 & 20 & 48 & 3.00 & 320 & 56 & 22 & 9.25 & 9.25 \\
\hline S5 & 498 & 7.58 & 624 & 292.50 & 90 & 18 & 24 & 5.5 & 213 & 55 & 52 & 7.53 & 7.53 \\
\hline S6 & 491 & 7.50 & 618 & 279 & 85 & 16 & 39 & 2.50 & 235 & 52 & 22 & 12 & 12 \\
\hline S7 & 525 & 7.54 & 603 & 295.50 & 100 & 11 & 23 & 4.00 & 288 & 34 & 21 & 11.02 & 13 \\
\hline
\end{tabular}

TDS total dissolved solids (mg/l), EC electrical conductivity $(\mu \mathrm{S} / \mathrm{cm}$ and $\mathrm{pH}$ unit $\mathrm{pH}$ 
Table 2:- Descriptive Statistics of hydro chemical data of water springs

\begin{tabular}{|l|l|l|l|l|l|l|l|l|l|l|l|l|l|}
\hline Statistic & TDS & pH & $\mathrm{EC}$ & $\mathrm{TH}$ & $\mathrm{Ca}^{2+}$ & $\mathrm{Mg}^{2+}$ & $\mathrm{Na}^{+}$ & $\mathrm{K}^{+}$ & $\mathrm{HCO}_{3}^{-}$ & $\mathrm{Cl}^{-}$ & $\mathrm{SO}_{4}^{2-}$ & $\mathrm{NO}_{3}^{-}$ & $\mathrm{SiO}_{2}$ \\
\hline Min & 491 & 7.50 & 603 & 279.50 & 85 & 10 & 23 & 1.72 & 213 & 34 & 21 & 4.23 & 5.70 \\
\hline Max & 592 & 7.60 & 752 & 322 & 110 & 20 & 53 & 5.15 & 320 & 78 & 52 & 12.00 & 13 \\
\hline Mean & 541.29 & 7.54 & 670.29 & 297.50 & 95.57 & 14.4 & 40.14 & 3.01 & 268.43 & 57.57 & 30.23 & 7.99 & 8.84 \\
\hline SD & 39.31 & 0.04 & 55.98 & 16.87 & 9.00 & 3.78 & 12.43 & 1.18 & 37.11 & 13.53 & 13.60 & 2.87 & 2.78 \\
\hline
\end{tabular}

Mechanisms influencing the chemistry and water-rock interaction Processes:-

The ratio of $\mathrm{Na}+\mathrm{k}+/(\mathrm{Na}++\mathrm{Ca} 2+)$ and $\mathrm{Cl}^{-} /\left(\mathrm{Cl}^{-}+\mathrm{HCO}_{3}^{-}\right)$as a function of TDS are widely employed to determine the processes of dissolved chemical constituents, such as precipitation, rock and evaporation dominance (Gibbs 1970,1971 ). According to the Gibbs classification the groundwater water samples of the study area indicate that evaporation dominance mechanisms control the chemistry of the groundwaters of the area. (Figure 2a and b). Another factor may be involved in the control of water chemistry such as dissolution and precipitation of rocks minerals in the study area .Mineral equilibrium calculations for groundwater are useful in predicting the presence of reactive minerals in the groundwater system and estimating mineral reactivity. By using the saturation index (SI) approach, it is possible to predict the reactive mineralogy of the subsurface from groundwater data without collecting the samples of the solid phase and analyzing the mineralogy (Deutsch 1997, Rouabhia et al, 2012). In the present study, equilibrium partial pressure of $\mathrm{CO} 2$, saturation indices (SI) with respect to carbonate (aragonite, calcite and dolomite) and to siliceous (quartz, chalcedony and amorphous silica) minerals were calculated based on the following equation (Lloyd and Heathcoat 1985):

$$
\mathrm{SI}=\log \left(\mathrm{IAP} / \log \mathrm{K}_{\mathrm{s}}(\mathrm{T})\right)
$$

Where IAP is the ion activity product of the solution, and $\mathrm{Ks}(\mathrm{T})$ is the equilibrium constant of the reaction considered at the temperature $\mathrm{T}$.

The computed values of SI and pCO2 for all minerals are summarized in (Table 3). For the stage period, the calculated values appear to be considerably higher than atmospheric pressure $\left(10^{-3.5}\right)$ with values varying between to $1.1010^{-2}$ to $0.6010^{-2} \mathrm{~atm}$. The elevated values can be explained that the travertine aquifer is opened to the soil CO2. All the considered ground waters are in oversatured with respect to aragonite, calcite and to dolomite (SI>0), which means that they are oversaturated for precipitation of aragonite, calcite and dolomite, suggesting that these carbonate mineral phases are present in the study area and carbonate mineral phases may have influenced the chemical composition of this ground waters. Generally, groundwater are saturated with respect to quartz (SI $>0$ ) and under saturated $(\mathrm{SI}<)$ with respect to chalcedony and under saturated with respect to amorphous silica, and these siliceous minerals can influence the concentrations of the dissolved $\mathrm{SiO}_{2}$ in groundwater.
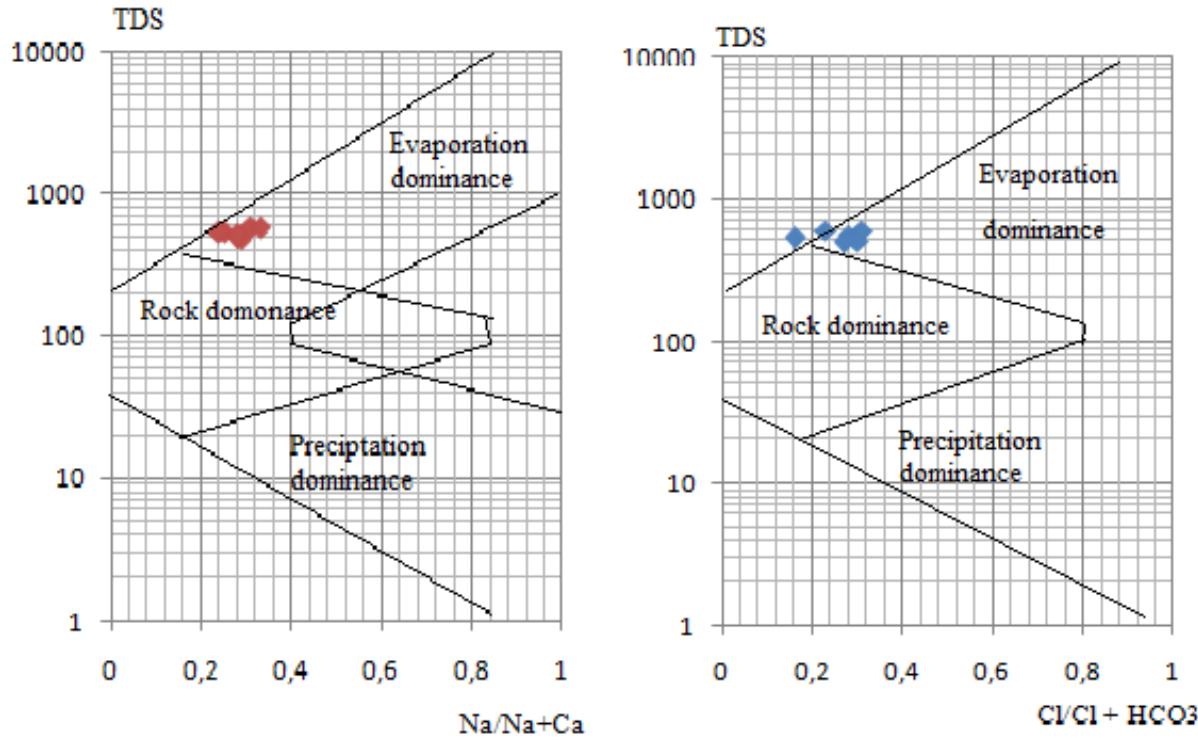

Fig 2:- Plot of some groundwater samples in the Gibbs diagram (a: TDS vsNa/Na+Ca ; b: TDSvs $\mathrm{Cl} / \mathrm{Cl}+\mathrm{HCO} 3$ ) 
Table 3:- Saturation indexes and equilibrium partial pCO2 as computed with PHREEQC.

\begin{tabular}{|c|c|c|c|c|c|c|c|}
\hline ID & Aragonite & Calcite & Dolomite & Chalcedony & Quartz & SiO2 & pCO2 10 $0^{-2}$ atm \\
\hline S1 & 0.50 & 0.50 & 0.31 & -0.31 & 0.11 & -1.15 & 0.85 \\
\hline S2 & 0.30 & 0.44 & 0.33 & -0.43 & 0.00 & -1.27 & 0.76 \\
\hline S3 & 0.33 & 0.48 & 0.50 & -0.47 & -0.04 & -1.31 & 1.10 \\
\hline S4 & 0.40 & 0.54 & 0.80 & -0.26 & 0.17 & -1.10 & 0.86 \\
\hline S5 & 0.22 & 0.37 & 0.58 & -0.35 & 0.08 & -1.19 & 0.60 \\
\hline S6 & 0.22 & 0.32 & 0.26 & -0.15 & 0.28 & -0.91 & 0.80 \\
\hline S7 & 0.37 & 0.51 & 0.41 & -0.11 & 0.31 & -0.95 & 0.89 \\
\hline
\end{tabular}

\section{Hydrochemical Facies:}

The chemical data obtained from waters springs samples are plotted on a Piper trilinear diagram (1944) to understand the hydrogeochemical regime in the study area during the stage period. The piper diagram (Fig. 5) constructed using Diagram Scientific Software shows the relative concentrations of the different ions of analyzed water samples. One main hydro chemical facies $(\mathrm{Ca}-\mathrm{HCO} 3)$ type, were identified based on the concentrations of the major ions, which indicates the dominance of carbonate rocks in the area.

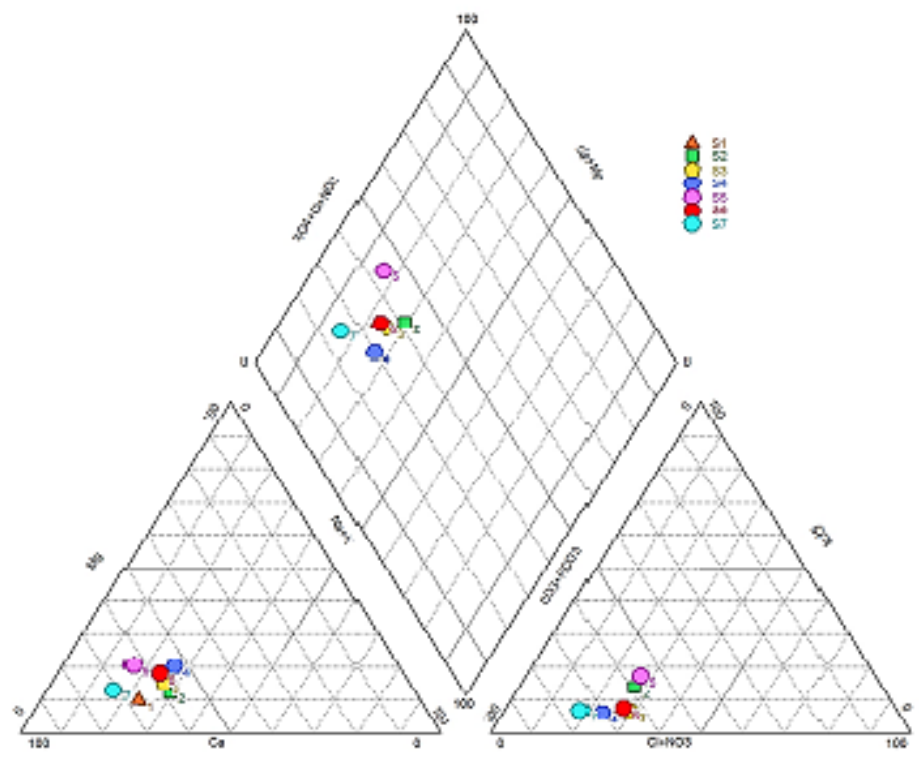

Fig 3:- Trilinear Piper diagram

\section{Drinking Water Purposes:- Physical Parameters:-}

From the table1, the $\mathrm{pH}$ from springs water of the travertine aquifer is found to be ranging from a minimum of 7.50 to a maximum of 7.60 with a mean of 7.54. These values show that the waters are moderate to slightly alkaline. All samples were found to below than the permissible limit of (6.5 to 8.5) prescribed by WHO (2011) for drinking water. Total Dissolved Solids (TDS) are the total amount of mobile charged ions, including minerals, salts or metals dissolved in a given volume of water. Total dissolved solids (TDS) varied from 491 to $592 \mathrm{mg} / \mathrm{l}$ with a mean valueof $541.29 \mathrm{mg} / \mathrm{l}$. As per TDS classification, $100 \%$ of the springs are fresh (TDS <1,000) water type (Freeze and Cherry, 1979). Electrical conductivity is the numerical expression of the ability of a water sample to carry an electric current and could be a sign of productivity of the water body. Results from this study showed that values of conductivity are ranging between 603 to $752 \mu \mathrm{S} / \mathrm{cm}$ with an average of $670.29 \mu \mathrm{S} / \mathrm{cm}$. According to WHO guidelines, waters of the study area show a slightly mineralization and EC values are between the minimum desirable and maximum

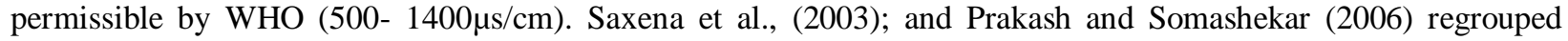
waters into three classes, fresh water if the EC $<1500 \mu \mathrm{S} / \mathrm{cm}$, brackish water if the EC is between $1500-3000$ $\mu \mathrm{S} / \mathrm{cm}$, and salt water if the EC> $3000 \mu \mathrm{S} / \mathrm{cm}$. According to this classification, all samples waters of the springs are freshwater and were used to the drinking and domestic purposes. 
In groundwater, hardness is formed mainly due to carbonate, bicarbonate and chloride of $\mathrm{Ca} 2+$ and $\mathrm{Mg} 2+. A s$ a water quality parameter, TH values can be used to classify water for domestic, agriculture and industrial uses. Total hardness (TH) ranges from 400.50 to $650 \mathrm{mg} / \mathrm{l}$ with an average value of $557.70 \pm 88.66 \mathrm{mg} / \mathrm{l}$. According to WHO standards, the most desirable limit is $300 \mathrm{mg} / \mathrm{l}$ and the maximum allowable limit of $\mathrm{TH}$ for drinking is $600 \mathrm{mg} / \mathrm{l}$. The classification of groundwater based on $\mathrm{TH}$ shows that a majority of the groundwater samples of the study area falls in the hard to very hard water category (WHO, 2011). Hence, classification of the groundwater of the study area based on total hardness (Sawyer and McCarthy, 1967) has been carried out and is presented in Table 3. Based on TH in the study area all samples fall under very hard class. According to WHO guidelines (2011) and Sawyer and McCarthy (1967), waters of springs are suitable for drinking and domestic purposes.

\section{Major Cations and Anions:-}

The concentration of $\mathrm{Ca}^{2+}$ in the study area ranges from 85 to $110 \mathrm{mg} / \mathrm{l}$ with an average of $95.57 \mathrm{mg} / \mathrm{l}$. WHO guidelines, (2011) did not specify a permissible limit for calcium in drinking water, but stated that calcium permissible limit in groundwater should be $75 \mathrm{mg} / \mathrm{l}$. according to the WHO (2011) guidelines; groundwater samples in the study area are considered not acceptable for drinking purpose.

The major source of $\mathrm{Ca} 2+$ in the groundwater is due to dissolution carbonate minerals from rocks of this area. $\mathrm{Mg} 2+$ contents islow in the water samples of the study area, ranges from 10 to $20 \mathrm{mg} / \mathrm{l}$ with a mean value of $14.40 \mathrm{mg} / \mathrm{l}$. we can be observed from the tables (Table1) that magnesium concentration from water samples is very low and safe for drinking and domestic uses. Sodium $\left(\mathrm{Na}^{+}\right)$contents in waters springs ranges from 23 to $53 \mathrm{mg} / \mathrm{l}$ with a mean value of $40.14 \mathrm{mg} / \mathrm{l}$. According to WHO (2011) standards, the maximum admissible limit is $200 \mathrm{mg} / \mathrm{l}$. Waters samples of springs show concentration of $\mathrm{Na}^{+}$below the permissible limit (WHO2011). Potassium $\left(\mathrm{K}^{+}\right)$concentration ranges from 1.72 to $5.15 \mathrm{mg} / \mathrm{l}$ with an average value of $3.01 \mathrm{mg} / \mathrm{l}$. The majority of samples are below $2 \mathrm{mg} / \mathrm{l}$ and there is no threat from potassium in waters samples.

HCO3- is easily dissolve in water and usually originates from weathering of feldspars and ferro-magnesium minerals by carbonic acid (Monjerezi et al., 2012). HCO3- is easily dissolve in water and usually originates from weathering of feldspars and ferro-magnesium minerals by carbonic acid (Monjerezi et al., 2012). As well, it comes from dissolution of carbonate rocks and water-rock interaction (Murad et al., 2011). The bicarbonates (HCO32- is the dominant anion and the contents vary from 213 to $320 \mathrm{mg} / \mathrm{l}$ with a mean of $268.42 \mathrm{mg} / \mathrm{l}$. Although, there are no exact permissible limits for bicarbonate in WHO guidelines (2011), the presence of HCO3- in drinking water should not exceed $500 \mathrm{mg} / \mathrm{l}$ in order to be safe for human consumption (Table1). A concentration of chlorides $\left(\mathrm{Cl}^{-}\right)$in water springs oscillates from 34 to $78 \mathrm{mg} / \mathrm{l}$ with a mean value of $57.57 \mathrm{mg} / \mathrm{l}$. The desirable limit of Chloride for drinking water is specified as $250 \mathrm{mg} / \mathrm{l}$ as per WHO (2011) and all the samples are under this limit. The concentration of sulfates $\left(\mathrm{SO}_{4}^{2-}\right)$ varies from 21 to $52 \mathrm{mg} / \mathrm{l}$ with a mean value of $30.60 \mathrm{mg} / \mathrm{l}$, and $100 \%$ of water sample are within allowed limit and can be used for human consumption.

Nitrates $\left(\mathrm{NO}_{3}^{-}\right)$concentration from springs, ranges from 4.23 to $12 \mathrm{mg} / \mathrm{l}$ an average of $7.99 \mathrm{mg} / \mathrm{l}$. $100 \%$ of the samples are within the permissible limit of $50 \mathrm{mg} / \mathrm{l}$ (WHO,2011). Relatively higher concentrations were observed in samples from the S6 and S7 located near the agricultural areas, where potential sources of nitrate contamination are more prevalent. Concentrations between 0 to $40 \mathrm{mg} / \mathrm{l}$ are generally safe for human adults and livestock; and do not use for human infants (Khanfar, 2010).

\section{Suitability for Irrigation:- Sodium Adsorption Ratio:-}

Water is excellent for irrigation purposes if the SAR is under 10 (Richards,1954). The SAR values are calculated according to the following formula:

$$
\mathrm{SAR}=\mathrm{Na}^{+} /\left(\mathrm{Ca}^{2+}+\mathrm{Mg}^{2+} /\right)^{1 / 2}
$$

The concentration $\mathrm{Ca}^{2+}+\mathrm{Mg}^{2+}$ and $\mathrm{Na}^{+}$are in meq/l

There is a significant relationship between SAR values of irrigation water and the extent to which sodium is absorbed by the soils. If water used for irrigation is high in sodium and low in calcium, the cation exchange complex may become saturated with sodium. This can destroy the soil structure owing to dispersion of the clay particles. Water having SAR $<10$ are excellent and suitable for all types of crops and all types of soils, except for those crops, 
which are sensitive to sodium. The calculated SAR values in the groundwater samples of travertine aquifer are found to vary from 0.68 to 1.42 with a mean of 1.25 (Table 4 ).

\section{Residual Sodium Carbonate:-}

The high concentration of bicarbonate ions in water provokes the precipitation of calcium and magnesium as carbonates and then the proportion of sodium in the soil increases. The RSC is calculated using the following equation:

$$
\mathrm{RSC}=(\text { Alkalinity } \times 0.0333)\left(\mathrm{Ca}^{2+}+\mathrm{Mg}^{2+}\right)
$$

The concentration of alkalinity values in $\mathrm{mg} / \mathrm{l}$ and $\mathrm{Ca}^{2+}+\mathrm{Mg}^{2+}$ are in meq/l.

Irrigation water having RSC values greater than $5 \mathrm{meq} / \mathrm{l}$, have been considered harmful to the growth of plants, whilewaters with RSC values $>2.5 \mathrm{meq} / \mathrm{l}$ are unsuitable for irrigation. An RSC value between 1.25 and $2.5 \mathrm{meq} / \mathrm{l}$ isconsidered as the marginal quality and value $<1.25 \mathrm{meq} / \mathrm{l}$ as the safe limit for irrigation (Richards, 1954). The estimated RSC values in the groundwater samples of travertine aquifer are found to vary from 1.24 to $4.64 \mathrm{meq} / \mathrm{l}$ with a mean of 2.89 (Table 4). According to RSC values; $86 \%$ samples are unsuitable for irrigation (Richards, 1954).

\section{PercentSolubleSodium (SSP):}

$$
\mathrm{SSP}=[\mathrm{Na}+/(\mathrm{Ca}+2+\mathrm{Mg}+2+\mathrm{Na}+)] \times 100
$$

Where, $\mathrm{Ca} 2+, \mathrm{Mg} 2+$ and $\mathrm{Na}+$ are concentrations in meq/l.

SSP values less or equal to 50 indicates good quality water while values greater than 50 are contrary and unsuitable for irrigation (Wilcox, 1955). SSP values ranged between with a mean of 16.52 to29.53\%with a mean of $24.23 \%$ (Table 4). The soluble percent sodium concentration in all samples belongs to the excellent to good categories and is used to agricultural purposes.

\section{Magnesium Ratio:-}

A ratio namely index of magnesium hazard was developed by Paliwal (1972) and was calculated by the following equation:

Where, all the ions are expressed in meq/l.

$$
\left.\mathrm{Mg}^{2+} \text { Ratio }=100 \times\left[\mathrm{Mg}^{2+} / \mathrm{Ca}^{2+}+\mathrm{Mg}^{2+}\right)\right]
$$

Magnesium hazard oscillated between 13.11 and $27.72 \%$ with a mean value of $20.55 \% .100 \%$ of samples fall below the permissible limit of $50 \% 1$ indicating the favorable effect on crop yield and decrease in soil alkalinity (Table 4). In the study area all of the samples are suitable for agricultural purposes regarding Magnesium hazard.

Table 4:- Results of the calculations of SAR, SSP, RSC, and Mg hazard

\begin{tabular}{|c|c|c|c|c|}
\hline ID & SAR & SSP (\%) & RSC & Mg (\%) \\
\hline S1 & 0.78 & 23.07 & 2.62 & 13.11 \\
\hline S2 & 1.42 & 29.53 & 2.77 & 17.39 \\
\hline S3 & 1.31 & 26.73 & 3.07 & 20.80 \\
\hline S4 & 1.27 & 26.88 & 4.64 & 27.72 \\
\hline S5 & 0.97 & 22.51 & 1.24 & 25.64 \\
\hline S6 & 1.07 & 24.39 & 2.24 & 23.83 \\
\hline S7 & 0.68 & 16.52 & 3.68 & 15.39 \\
\hline Mean & 1.25 & 24.23 & 2.89 & 20.55 \\
\hline
\end{tabular}

\section{Conclusions:-}

.In the study area, the waters springs of the travertine aquifer of Guelma was important water resources in this area. It is the main water resource used for drinking and agricultural purposes. Therefore, determining the source and mechanism controlling the water chemistry is out lined in this study. Hence, analysis of the major ions in groundwater was carried out. The principal factor responsible of the chemical composition of the water is evaporation dominance, dissolution and precipitation of some minerals. Physicochemical analysis showed that the waters springs are suited for drinking and domestic uses due to low amounts of cations and anions, except for 
calcium witch preset an amount over the permissible limit of WHO. According to SAR, SSP, RSC and Mg hazard, ground water is suitable for irrigation uses.

\section{Acknowledgements:-}

We would like to thank Ontonio Paulido Bosch (University of Almeria) for the help and assistance and to the reviews.

\section{References:-}

1. Benmarce, K. (2007). Physicochemical and isotopic characteristics of groundwater in Guelma region. PhD of Science, University Badji Mokhtar, Annaba, Algeria, p 135.

2. Chouabbi, A. (1987).Geological study of the HammamN'bails area (SE Guelma, Constantine region, Algeria), PhD Thesis, University Paul Sabatier Toulouse, France, $p 123$.

3. Deutsch, W.J .(1997). Groundwater geochemistry: fundamentals and application to contamination. CRC Press, Boca Raton.

4. Freez, R.A., Cherry, J.A. (1979). Groundwater. Prentice Hall Inc., Englewood Cliffs, N.J.

5. Gibbs, R.(1970). Mechanism controlling world river water chemistry. Science 170:1088-1090.

6. Gibbs, R. (1971). Mechanism controlling world river water chemistry:evaporation-crystallization process. Science 172:871-872.

7. Khanfar,A.R. (2010).Dissolved nitrogen in drinking water resources in Al-Mahareth village of Assir - Saudi Arabia. Saudi Journal of Biological Sciences (2010) 17, 265-268.

8. Lloyd, J.W. and Heathcote, J.A.(1985). Natural inorganic hydrochemistry in relation to groundwater. Oxford University Press, New York.

9. Monjerezi, M., et al. (2012). The hydrogeochemistry of groundwater resources in an area with prevailing saline groundwater, lower Shire Valley, Malawi. Journal of African Earth Sciences, 68 (1), 67-81.

10. Murad, A., et al. (2011). Hydrogeochemical characterization and isotope investigations of a carbonate aquifer of the northern part of the United Arab Emirates. Journal of Asian Earth Sciences, 40, 213-225.

11. Paliwal, K.V. ( 1972).Irrigation with saline water. Monogram No. 2 (Newseries), IARI, New Delhi, $p 198$.

12. Prakash,K. L., Somashekar, R. K. (2006). Groundwater quality - Assessment on Anekal Taluk, Bangalore Urban district, India. Journal of Environmental Biology. 27(4): 633-637.

13. Parkhurst, D.L.,Appelo, C.A.( 1999). User's guide to PHREEQC (version 2)-acomputer program for speciation, batch-reaction, one-dimensional transport, and inverse geochemical calculations. US Geological Survey WaterResources Investigation Report. US Geological Survey, Reston, pp 99-4259.

14. Piper, A.M. (1944). A graphical procedure in the chemical interpretation of groundwater analysis. Trans. Amer. Geophy. Union, 25, 914-928.

15. Richards, L.A. (1 954). Diagnosis and improvement of saline and alkaline soils, US Department ofAgriculture HandBook.

16. Rouabhia, A. et al. (2008). Impact of human activities on quality and geochemistry of groundwater in the Merdja area, Tebessa, Alegria. Environmental Geology. Doi: 10.1007/s00254-008-1225-0.

17. Saxena, V.K. et al. (2003). Use of chemical parameters to delineation fresh water resources Paotharlank Island, India. Environmental Geology. 44(5): 516-521.

18. Sawyer, G.N., McMcartly, D.L. ( 1967). Chemistry of sanitary engineers, 2nd edn. McGraw Hill, New York $p 518$

19. Simler, R. (2003). Diagram: hydrochemistry software. Avignon, France.

20. Vila, J.M. (1980). La chaîne alpine d'Algérie orientale et des confins Algéro-Tunisiens. PhD of Science, University Pierre et Marie Curie, Paris VI.

21. Wilcox, L.V. (1955). Classification and use of irrigation waters. US Dept Agric Circ, Washington, DC, p 969.

22. WHO. (2011).Guidelines for drinking water quality, 4th edn. World Health Organization, Geneva. 